\title{
CLIFTON DURANT HOWE
}

In the death of Dr. Clifton Durant Howe, M.S., Ph.D., L.L.D., Dean Emeritus of the Faculty of Forestry, University of Toronto, on Pebruary. 22,1946 , in Toronto, the forestry profession lost one of it's most illustrious and kindliest members.

Born in Newfane, Vermont, U.S.A., Dr. Howe graduated from the University of Vermont in 1901 with the degrees of B.A. and M.S. In 1904 he obtained his Ph.D. degree from the University of Chicago. In 1900-01 he was instructor in biology at the University of Vermont. Later he was Fellow and Assistant in Botany at the University of Chicago, and instructor and assistant director of dendrology at the Biltmore Forest School in North Carolina. In 1907 the first forestry school in Canada was established by Dr. B. E. Fernow at the University of Toronto, and Dr. Howe became a member of the teaching staff of that school the following autumn.

During the next decade Dr. Howe received widespread recognition, not only for his maturing teaching ability, but also for the earnestness and sincerity of his convictions. During this period his summers were spent in forestry field work in different regions of Canada, and one of his notable contributions was his initiation, under the Commission of Conservation at Ottawa, of basic government forest research policies.

In 1919 Dr. Howe was appointed Dean of the Faculty of Forestry. In the next twenty years he took a leading part in trying to make the public conscious of forests and forestry. He gave innumerable public addresses and was a prolific writer. In addition he played a leading role on the professional side in all organizations concerned with forestry practice. Appreciation of this was reflected in his appointment to numerous executive councils. He was president of the Canadian Society of Forest Engineers for three years, chairman of the Ontario Forestry Board for six years, chairman of the Associate Committee of Forestry of the National Research Council, also for six years. He was for a term president of the Canadian Forestry Association and for several years contributed an article nearly every month to the As. sociation's official magazine, Forest and Outdoors.

In 1942 in recognition of his outstanding service to the profession the Canadian Society of Forest Engineers, of which he had been a member since 1909 , made Dr. Howe a life member of the Society.

In 1943 the University of Toronto, in recognition of his great con. structive contribution to the university by his teaching, and to this country by his public service, conferred upon him the degree of Doctor of Laws (LL.D.) honoris causa.

Although he retired in 1941 Dr. Howe kept in touch with the university and with many old friends and students up to his death at the age of seventy-one years. The simplicity of his nature, his great love of birds and trees, his innate gentleness, and his unfailing helpfulness will forever be remembered by those privileged to call him friend.

Dr. Howe is survived by his widow, the former Elsie Marion Newton, his daughter, Mrs. Harold I. Williams (Alice) of Lynn, Massachusetts, and two brothers, Arthur and Herman Howe, both of Newfane, Vermont. 